\title{
Detection of Sclerotinia sclerotiorum in soybean seeds by conventional and quantitative PCR techniques ${ }^{1}$
}

\author{
Luana da Silva Botelho², Ellen Noly Barrocas ${ }^{3 *}$, \\ José da Cruz Machado ${ }^{4}$, Rayana de Sá Martins ${ }^{5}$
}

\begin{abstract}
Sclerotinia sclerotiorum, the etiological agent of the "white mould" in soybean, is responsible for severe losses in this crop and soil contamination. The introduction and dissemination of the disease can made through the use of seed lots contaminated with sclerotia and by seeds infected by mycelium. Therefore, seed health quality is one aspect to be monitored by means of health testing before to sowing time. In this study conventional and quantitative PCR techniques were used to assess their viability to detect S. sclerotiorum in artificially and naturally infected soybean seed samples. For that, seeds were inoculated by osmotic conditioning technique for $0,24,48$ and 72 hours of contact of the seed with the fungal colony and mixed with healthy seeds generating incidence levels of 1, 2, 10,20 and $100 \%$ for each incubation time. The cPCR was sensitive to detect $S$. sclerotiorum in samples with at least incidence $1 \%$ inoculated for 72 hours while the qPCR detected the pathogen in all incidence/inoculum potential combinations. The conventional PCR was able to detect $0.25 \%$ of the incidence of S. sclerotiorum in soybean seed lots naturally infected added a preincubation step.
\end{abstract}

Index terms: seed healthy, molecular detection, seed borne pathogen, white mould.

\section{Detecção de Sclerotinia sclerotiorum em sementes de soja pelas técnicas de PCR convencional e quantitativo}

\begin{abstract}
RESUMO - Sclerotinia sclerotiorum causador do "mofo branco" na cultura da soja, é responsável por redução da produção e contaminação do solo. A introdução e disseminação da doença podem se dar pelo uso de sementes contaminadas com escleródios e por sementes infectadas pelo micélio. A qualidade das sementes deve ser monitorada por testes de sanidade antes da semeadura. Neste estudo foram utilizadas técnicas de PCR convencional e quantitativo para avaliar a viabilidade de uso das mesmas para a detecção de S. sclerotiorum em amostras de sementes de soja artificialmente e naturalmente infectadas. Para isso, as sementes foram inoculadas usando a técnica do condicionamento osmótico por $0,24,48$ e 72 horas de contato das sementes com a colônia do fungo e misturadas à sementes sadias gerando incidência de 1, 2, 10, 20 e 100\% para cada tempo de incubação. A técnica de cPCR foi sensível para detectar S. sclerotiorum em amostras com, no mínimo, incidência de 1\% inoculadas por 72 horas, enquanto que com o qPCR foi possível detectar o patógeno em todas as combinações incidência/potencial de inóculo. A PCR convencional foi capaz de detectar 0,25\% de incidência de S. sclerotiorum em lotes de sementes de soja naturalmente infectados adicionando-se uma etapa de pré-incubação das sementes.
\end{abstract}

Termos para indexação: sanidade de sementes, detecção molecular, patógeno de sementes, mofo branco.

\section{Introduction}

White mold of soybean caused by Sclerotinia sclerotiorum is a highly destructive disease that is capable of infecting species of great economic importance to Brazil as it is a cosmopolitan occurrence. The importance of this disease becomes even more impressive considering the participation of soybeans in the socio-economic development in agribusiness. Concerns with this pathogen are also justified because it is a necrotrophic fungus with a wide host range and could prevent the planting of crops in areas for periods until 10 years (Boland and Hall, 1994). The widespread and devastating occurrence of white mold in soybean cultivation in Brazil has caused great concern among segments of this production since it is a disease
${ }^{1}$ Submitted on 10/08/2014. Accepted for publication on 12/17/2014. ${ }^{2}$ Departamento de Microbiologia Agrícola, Instituto Federal do Norte de Minas Gerais, Caixa Postal 3037, 38680000 - Arinos, MG, Brasil. ${ }^{3}$ Department of Plant and Environmental Sciences, Copenhagen University, 2360 - Taastrup, Denmark.

\footnotetext{
${ }^{4}$ Departamento de Fitopatologia, Universidade Federal de Lavras, Caixa Postal 3037, 37200-000 - Lavras, MG, Brasil.

${ }^{5}$ Departamento de Ciências Florestais, Universidade Federal de Lavras, Caixa Postal 3037, 37200-000 - Lavras, MG, Brasil.

*Corresponding author < ellennoly@gmail.com>
} 
that requires special attention. Because of its nature and wide spread, this pathogen has been considered denominated as a non- quarantine pest regulated with a zero tolerance level in seed certification programs in Brazil (Machado and Pozza, 2005).

Despite the control of white mold being a serious challenge for the nation's agriculture, since it requires must involve different management measures, the use of seeds with certified health quality appears as the starting point to minimize the problems caused by this disease. It is known that the seeds carrying the inoculum of this pathogen, in the form of dormant mycelium or as sclerotia mixed with seeds, may be an important factor in introduction and re-introduction in the same fields.

The improvement of diagnostic methods for pathogens in seeds is still a challenge for quality control programs all over the world. Conventional methods for detecting S. sclerotiorum include the incubation of seeds on filter paper (blotter and roll tests) and incubation of seeds in semi-selective medium of agar bromophenol blue (NEON). Both methods have some disadvantages such as long incubation periods and difficulties in distinguishing between S. sclerotiorum and other organisms also present in the seeds.

Molecular methods based on the technique of Polymerase Chain Reaction (PCR) have been investigated for the detection of different pathogens in seeds whose morphological characteristics are very similar (Mbofung and Pryor, 2010; Glynn Edwards, 2010; Ioos et al., 2012). These techniques show promise for this purpose, since they have high sensitivity, specificity, and they have the advantage of evaluating a large number of samples in a short period time and may be used in certification programs.

In this work the objective was to evaluate the viability of using conventional PCR (cPCR) and quantitative PCR (qPCR) for detection of S. sclerotiorum in artificially and naturally infected soybean seeds.

\section{Material and Methods}

\section{Origin, isolation of isolates and specificity of the primers}

For the development of this work the fungal isolates were obtained from infected seeds as indicated in Table 1. The fungi were grown on potato dextrose agar medium, $\mathrm{Merck}^{\circledR}$, (PDA) following the manufacturer's protocol. After confirmation of their identities and purity were transferred to Petri dishes with $15 \mathrm{~cm}$ on the same medium, maintained in incubation at a temperature of $20 \pm 2{ }^{\circ} \mathrm{C}$ and a photoperiod of $12 \mathrm{~h}$ for seven days for $S$. sclerotiorum and at a temperature of $25 \pm 2{ }^{\circ} \mathrm{C}$ and a photoperiod of $12 \mathrm{~h}$ for seven days for the other fungi chosen for this study. After growth of each isolate, the mycelium produced on the surface was scraped, washed with sterile water and the DNA was extracted with the Wizard Genomic DNA Purification kit $^{\circledR}$ following the manufacturer's protocol (Promega). The quality of each DNA $10 \mu \mathrm{L}$ was checked in $1.0 \%$ agarose gel in TBE buffer at $100 \mathrm{~V}$ for approximately $1 \mathrm{~h}$. The gel was stained with Red Gel ${ }^{\circledR}$ (Biotium) and the PCR products were observed in a Transiluminator UV L-PIX - Transiluminator (Loccus-Biotecnologia). All DNAs samples were quantified in a Nano Drop spectrophotometer 3300 (Thermo Scientific).

The specificity was assessed through cPCR technique using all isolates described in Table 1. For that it was used the primer SSFWD-5'GCTGCTCTTTCGGGGCCTTGTA3' and SSREV-5'TGACATGCACTCAATACCAAGCTG3', by Freeman et al. (2002) wich amplify a fragment with 278 base pairs.

The total reaction volume of $25 \mu \mathrm{L}$ of Top Taq Master $\mathrm{Mix}^{\circledR}$ (Qiagen) containing $0.625 \mathrm{M}$ of each primer and $2 \mu \mathrm{L}$ of DNA template $(50 \mathrm{ng})$. The amplifications were performed in the thermocycler Multigen (Labnet, NJ, USA). The conditions of the cycle for amplification were $95{ }^{\circ} \mathrm{C}$ for 10 min. followed by a total of 30 cycles of denaturation $94{ }^{\circ} \mathrm{C}$ for $30 \mathrm{~s}$., carrying out the "touchdown" technique at annealing temperatures (decreasing $1{ }^{\circ} \mathrm{C}$ per cycle of $72{ }^{\circ} \mathrm{C}$ to $65^{\circ} \mathrm{C}$ ) for $1 \mathrm{~min}$. and an extension at $72{ }^{\circ} \mathrm{C}$ for $1 \mathrm{~min}$. and a final extension at $72{ }^{\circ} \mathrm{C}$ for $10 \mathrm{~min}$. (Freeman et al., 2002). Was evaluated $6 \mu \mathrm{L}$ for each PCR product in $1.0 \%$ agarose gel in TBE buffer at $100 \mathrm{~V}$ for approximately $2 \mathrm{~h}$. The gel was stained with Red Gel ${ }^{\circledR}$ (Biotium) and the PCR products were observed in a Transiluminator UV L-PIX - Transiluminator (Loccus-Biotecnologia).

Inoculation of S. sclerotiorum in soybean seeds and sensitivity assay

Soybean seeds, from the Conquista cultivar, were sterilized with $1 \%$ sodium hypochlorite for $30 \mathrm{~s}$, rinsed in distilled water and dried on germitest paper in laminar flow hood for $48 \mathrm{~h}$. The inoculation of seeds was performed with the isolate $S$. sclerotiorum code CMLAPS 242, through the physiological priming technique as described in literature (Machado et al., 2004). Soybean seed were distributed, in single layers, on pure colonies of S. sclerotiorum with 5 days old developed on PDA medium plus mannitol, adjusted to $-1.0 \mathrm{MPa}$, according to MPPS software (Michel and Radcliffe, 1995). The seeds were incubated at temperature of $20 \pm 2{ }^{\circ} \mathrm{C}$ and photoperiod of $12 \mathrm{~h}$ for periods of 0,24 , 48 and $72 \mathrm{~h}$, here named inoculum potential $(\Psi)$. After each incubation time, the seeds were dried in a laminar flow hood for further mixture with healthy seeds. 
Table 1. Specificity of primers SSFWR SSREV in pure cultures of fungi from different cultures.

\begin{tabular}{|c|c|c|}
\hline Specie (isolate) & Host & $\begin{array}{c}\text { Amplification } \\
\text { SSFWR/SSREV }\end{array}$ \\
\hline S. sclerotiorum (CMLAPS 01) & Soybean & + \\
\hline S. sclerotiorum (CMLAPS 02) & Soybean & + \\
\hline S. sclerotiorum (CMLAPS 05) & Soybean & + \\
\hline S. sclerotiorum (CMLAPS 04) & Sunflower & + \\
\hline S. sclerotiorum (CMLAPS 03) & Soybean & + \\
\hline S. sclerotiorum (CMLAPS 06) & Soybean & + \\
\hline S. sclerotiorum (CMLAPS 78) & Soybean & + \\
\hline S. sclerotiorum (CMLAPS 79) & Soybean & + \\
\hline S. sclerotiorum (CMLAPS 80) & Soybean & + \\
\hline S. sclerotiorum (CMLAPS 241) & Common bean & + \\
\hline S. sclerotiorum (CMLAPS 242) & Soybean & + \\
\hline S. sclerotiorum (CMLAPS 243) & Soybean & + \\
\hline S. sclerotiorum (CMLAPS 244) & Soybean & + \\
\hline S. sclerotiorum (CMLAPS 245) & Sunflower & + \\
\hline S. sclerotiorum (CMLAPS 246) & Common bean & + \\
\hline S. sclerotiorum (CMLAPS 247) & Common bean & + \\
\hline S. sclerotiorum (CMLAPS 248) & Sunflower & + \\
\hline S. sclerotiorum (CMLAPS 249) & Sunflower & + \\
\hline S. sclerotiorum (CMLAPS 250) & Sunflower & + \\
\hline S. sclerotiorum (CMLAPS 406) & Soybean & + \\
\hline S. sclerotiorum (CMLAPS 410) & Soybean & + \\
\hline S. sclerotiorum (CMLAPS 412) & Soybean & + \\
\hline S. sclerotiorum (CMLAPS 416) & Soybean & + \\
\hline S. sclerotiorum (CMLAPS 417) & Soybean & + \\
\hline S. sclerotiorum (CMLAPS 420) & Soybean & + \\
\hline S. sclerotiorum (CMLAPS 421) & Soybean & + \\
\hline S. sclerotiorum (CMLAPS 423) & Sunflower & + \\
\hline S. sclerotiorum (CMLAPS 424) & Sunflower & + \\
\hline S. sclerotiorum (CMLAPS 425) & Common bean & + \\
\hline Aspergillus flavus (CMLAPS 484) & Soybean & - \\
\hline Cercospora kikuchii (CMLAPS 255) & Soybean & - \\
\hline Cercospora sojina (CMLAPS 258) & Soybean & - \\
\hline Colletotrichum truncatum (CMLAPS 327) & Soybean & - \\
\hline Corynespora cassicola (CMLAPS 312) & Soybean & - \\
\hline Fusarium solani (CMLAPS 368) & Soybean & - \\
\hline Macrophomina phaseolina (CMLAPS 049) & Soybean & - \\
\hline Phomopsis sojae (CMLAPS18) & Soybean & - \\
\hline Phomopsis meridionalis (SI) & Soybean & - \\
\hline Botrytis cinerea $(\mathrm{SI})$ & Sunflower & - \\
\hline
\end{tabular}

Abreviations: CMLAPS $=$ Mycological Collection from Seed Pathology Laboratory, Lavras-MG, Brazil, $+=$ positive reaction, $-=$ negative reaction; SI $=$ without identification.

The sensitivity was evaluated by cPCR and qPCR. The DNA extractions, primers used and conditions of cycle were the same for both.

To determine the sensitivity of detection of S. sclerotiorum when associated to soybean seeds, portions of 100 seeds were prepared by mixing artificially infected seeds with healthy seeds, generating incidence levels of 1, 2, 10, 20 and
$100 \%$ for each incubation time described above. Each seed sample, was ground separately in a Basic IKA A11 grinder containing liquid nitrogen. The DNA for each sample was extracted, checked their quality and quantity as described before. The DNA extractions were made for each level of incidence/incubation time and the experiment was conducted in quintuplicate. To prevent contamination between samples, 
the mill was systematically cleaned and disinfected with $2 \%$ sodium hypochlorite solution after each sample changed.

For the cPCR the reactions were described previously. For qPCR the reaction was processed using a total volume of $20 \mu \mathrm{L}$ of reagent "SYBR Green PCR kit" (Qiagen) with 0.625 $\mu \mathrm{M}$ of each primer and $2 \mu \mathrm{L}$ of DNA template $(50 \mathrm{ng})$. The $\mathrm{Cq}$ values of each reaction were determined using the Rotor-Gene (Corbett) software version 1.7.75. by cycler Rotor-Gene 6500 (Corbett Research, Mortlake, Australia) with optimization of gain for each tube before the first acquisition of fluorescence. The qPCR experiment was conducted also in quintuplicate.

The specificity and sensitivity were evaluated in accordance with the guidelines: Minimum Information for Publication of Quantitative Real-Time PCR Experiments (Bustin, 2010).

Incidence and detection of S. sclerotiorum in naturally infected seeds using semi-seletive agar bromophenol blue medium (NEON) and cPCR

The $S$. sclerotiorum presence was analyzed in thirteen seed lots from different soybean production fields by NEON test and cPCR. Four hundred seeds/lot were distributed in eight Petri dishes with $15 \mathrm{~cm}$ diameter containing agar bromophenol blue medium (Brasil, 2009), which were then incubated in chambers at temperature of $20 \pm 2{ }^{\circ} \mathrm{C}$ and photoperiod of 12 hours for 5 days. The seeds were distributed maintaining equidistance between them.

After the incubation period, the incidence was assessed by the formation of a yellow halo around each seed. Then, all seeds from each lot were removed separately, ground and extracted their DNAs. The experiment was done with 4 replicates. The grind, DNA extraction and PCR protocol were followed as described above. In NEON test were considered the yellow halo around each seed as positive. In PCR test, were considered positive those in which at least showed band in one replication.

The NEON test in this experiment was performed to evaluate the incidence of $S$. sclerotiorum in seed lots naturally infected, as an incubation step and as reference to detection using cPCR technique.

\section{Results and Discussion}

\section{Specificity of the primers}

The evaluation of the PCR products through electrophoretic analysis in 1,0\% agarose gel, obtained from the amplification of DNA fragments of isolates with specific primers designed for S. sclerotiorum, generated bands of 278 base pairs, indicating specificity for the species in question. As for the other fungi found in soybean seeds such as Aspergillus flavus, Cercospora kikuchii, Cercospora sojina, Colletotrichum truncatum, Corynespora cassicola, Fusarium solani, Macrophomina phaseolina, Phomopsis sojae, Phomopsis meridionalis and Botrytis cinerea from sunflower seeds, the results were negative, confirming that the pair of primers was specific for the detection of $S$. sclerotiorum (Table 1).

As reported in literature, other primers have been described as successful for the detection of $S$. sclerotiorum for ascospores and in plant tissues infected by the pathogen (Yanni et al., 2009; Kim and Knudsen, 2008; Rogers et al., 2009). In this work these primers were tested in soybeans seeds inoculated with $S$. sclerotiorum but without success. Only the primers described by Freeman et al. (2002) showed good results when tested in soybeans seeds inoculated with S. sclerotiorum, in both types of PCR using the "touchdown" method. The touchdown PCR has been used to avoid amplification of non-specific sequences caused by phenolic compounds or other inhibitors, in PCR's reactions. This is important in seed pathogen's detection which some interference may reduce the sensitivity of detection and can generate false negative results (Barrocas et al., 2009). In addition to this one of the difficulties highlighted in the sanitary quality control of seeds has been the occurrence of pathogens in low incidence and low inoculum in the seeds.

Furthermore, for the detection of fungi, specifically in seeds, it is necessary that, whatever method adopted, the primer pair be tested for specificity and optimized for maximum sensitivity for pure fungal colony and pathogen in association with seeds. It is also important to test the primers published by other authors in different isolates of the region where the work is being developed. Variability naturally found among fungal isolates from the same species but from different regions or hosts can lead to contradictory results of detection. The primers used had already been tested by Freeman et al. (2002) for $S$. sclerotiorum isolates from other countries, as well as similar species, for that only brasilian isolates were used.

Inoculation of $S$. sclerotiorum in soybean seeds and sensitivity assay

According to results in Table 2 the cPCR wasn't enough sensitive to detect $S$. sclerotiorum in samples with low concentrations of this pathogen. In combinations with lower incidences (1 and 2\%) and lower inoculum potential (24 and 48 hours) the cPCR wasn't able to detect the fungi in samples evaluated. For the samples with the same incidence but 72 hours of the inoculum potential, only 2 from the 5 replicates were detected.

The cPCR was sensitive only to samples with incidences higher than $10 \%$, considering at least 24 hours of the inoculum potential. In this case this technique was able to detect the fungi in seeds in all replications. 
In assessing the qPCR (Table 2, Figure 1) it was possible to detect the pathogen in all replications of incidence/inoculum potential combination even in samples that were exposed to the pathogen for only $24 \mathrm{~h}$ and $1 \%$ of incidence.

Table 2. Amplification of genomic DNA from $S$. sclerotiorum by cPCR and qPCR at different levels of incidence in soybean seeds.

\begin{tabular}{cccc}
\hline Incidence (\%) & $\begin{array}{c}\text { Inoculum } \\
\text { potential (hrs) }\end{array}$ & $\begin{array}{c}\text { Results } \\
\text { cPCR }\end{array}$ & $\begin{array}{c}\text { Results } \\
\text { qPCR }\end{array}$ \\
\hline *Negative control & 0 & $0 / 5$ & $5 / 5$ \\
\hline \multirow{2}{*}{1} & 24 & $0 / 5$ & $5 / 5$ \\
& 48 & $0 / 5$ & $5 / 5$ \\
2 & 72 & $2 / 5$ & $5 / 5$ \\
\hline \multirow{2}{*}{10} & 24 & $0 / 5$ & $5 / 5$ \\
& 48 & $0 / 5$ & $5 / 5$ \\
& 72 & $2 / 5$ & $5 / 5$ \\
\hline \multirow{2}{*}{20} & 24 & $5 / 5$ & $5 / 5$ \\
& 48 & $5 / 5$ & $5 / 5$ \\
& 72 & $5 / 5$ & $5 / 5$ \\
\hline \multirow{2}{*}{100} & 24 & $5 / 5$ & $5 / 5$ \\
& 48 & $5 / 5$ & $5 / 5$ \\
& 72 & $5 / 5$ & $5 / 5$ \\
\hline$* *$ Positive control & 24 & $5 / 5$ & $5 / 5$ \\
& 48 & $5 / 5$ & $5 / 5$ \\
& 72 & $5 / 5$ & $5 / 5$ \\
\hline
\end{tabular}

*Negative control - seeds without inoculation.

**Pure culture from S. sclerotiorum CMLAPS 241.
In all extractions of DNA in seeds with different combinations of incidence/inoculum potential, the $\mathrm{Cq}$ values were between 16.77 and 29.09 and confirmed the presence of the pathogen in all inoculated samples (Figure 1). The eficiency (E) was 1.32 and $\mathrm{R}^{2}$ was 0.924 (Figure 2). The increase of fluorescence values $(\Delta \mathrm{Rn})$ was higher as the increased time of exposition the colony of the fungus $S$. sclerotiorum in artificial inoculation and wasn't observed increase in fluorescence in healthy seeds.

The osmotic conditioning technique used to inoculate seed, in this paper, ensured its infection at varying levels, as has been demonstrated for some pathosystems (Barrocas et al., 2014; Siqueira et al., 2014; Machado et al., 2004) and can be used as a tool that may help to validate techniques used for detecting pathogens in seeds. Therefore, it's recommended to use the seeds inoculated with that technique, as a first study on the detection sensitivity seed borne pathogens.

In this study, an intercalating dye SYBR Green ${ }^{\circledR}$ that, although less sensitive than probes showed satisfactory results in the detection of seed infected by S. sclerotiorum, even with low levels of infection, 1 and $2 \%$ in qPCR since the objective was to detect $S$. sclerotiorum in association with soybean seeds. The detection of this fungus was obtained in seeds with low incubation time and low incidence of infection in the seed samples tested. The qPCR technique showed good repeatability, unlike cPCR.

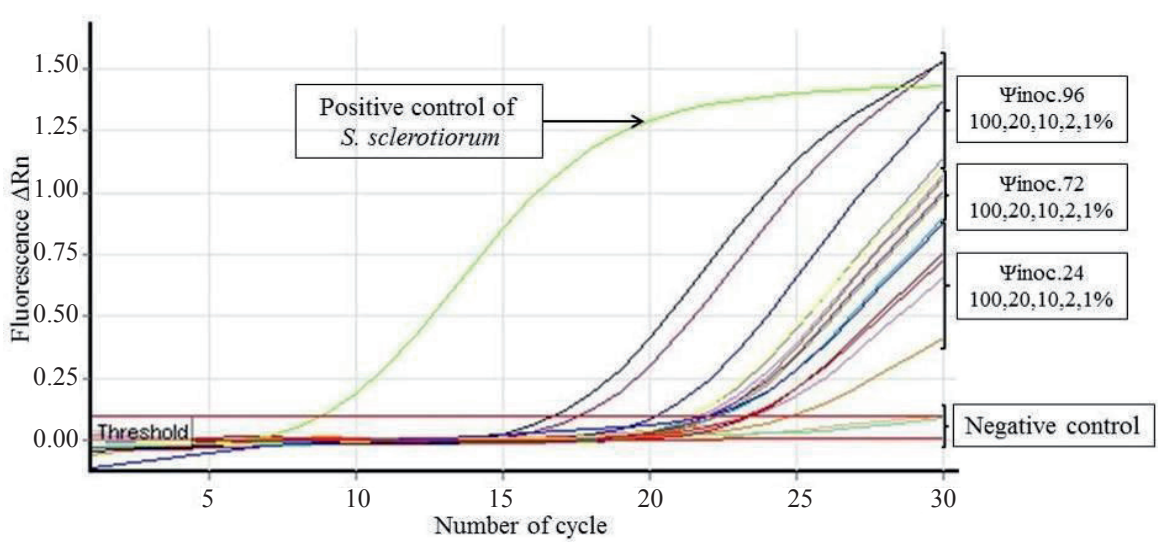

Figure 1. Amplification curves on the detection of S. sclerotiorum through quantitative polymerase chain reaction technique (qPCR) using SYBR ${ }^{\circledR}$ Green, indicating the increase of the fluorescence signal. Soybeans seeds healthy (Negative

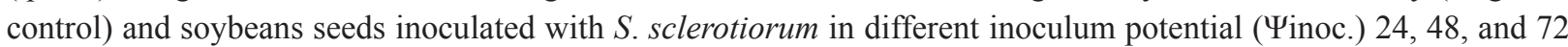
with incidences of $1,2,10,20$ and $100 \%$ respectively in each potential.

It is important to consider that the cPCR technique only indicates the presence or absence of the pathogen in a sample, which may be a limiting factor for the healthy tests in seed pathology. The detection and quantification 
of the pathogen in a sample of seeds have been important for some epidemiological studies of view have been used to examine diverse seedborne pathogens such as bacteria (Becker et al., 2011; Cottyn et al., 2011), fungi (Chen et al.,2013;
Duressa et al., 2012; Montes-Borrego et al., 2012; Ioos et al., 2012; Kuan et al., 2011) and viruses (Ling et al., 2011), including in detection for many seed borne pathogens in the same time (Feng et al., 2014).

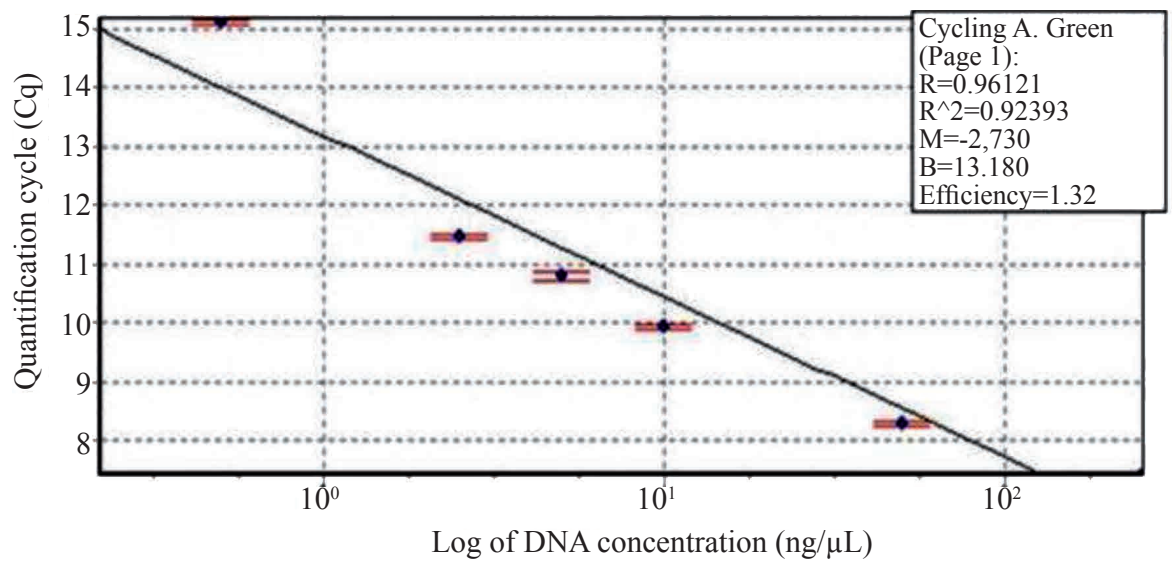

Figure 2. Quantitative polymerase chain reaction (qPCR) standard curve of the log of amount of S. sclerotiorum DNA, ranging from $250 \mathrm{ng} \mu \mathrm{L}^{-1}$ to $0,5 \mathrm{ng} \mu \mathrm{L}^{-1}$ per PCR versus the corresponding cycle quantitative $(\mathrm{Cq})$ values.

For molecular detection of S. sclerotiorum in soybean seeds in Brazil, where the presence of this fungus in seeds lots isn't accepted, the test may be recommended as a screening procedure, which aims to inform if the lot is infected or not.

For lots that are considered infected other complementary techniques should be used to indicate the incidence and viability of the pathogen in the samples. On the other hand, the qPCR technique may represent another form of information that can be used in the sanitary control of seeds. The quantification of pathogens in the seed lot, isn't considered in routine testing as for the recommendation of fungicide to be used in seed treatment. This information could be important, since the treatment of seeds with high inoculum quantity of pathogens may not produce desired results.

\section{Incidence and detection of S. sclerotiorum in naturally infected seeds}

According Table 3 the lots 1, 4, 7 and 9 showed S. sclerotiorum incidence of $0.5 \%, 0.5 \%, 0.25 \%$ and $0.5 \%$, respectively when were evaluated by agar bromophenol blue medium. The same lots showed positive results when analyzed by cPCR. The lots 1.4 and 7 showed bands in one replication and lot 9 in two replications. The other seed lots were negative when were evaluated by agar bromophenol blue medium and also in cPCR test.

Table 3. Detection of S. sclerotiorum in thirteen samples of soybean seed assessed by agar bromophenol blue medium and cPCR.

\begin{tabular}{ccc}
\hline Sample/ Method & $\begin{array}{c}\text { Agar bromophenol blue medium } \\
\text { (Positive seeds/sample) }\end{array}$ & $\begin{array}{c}\text { cPCR detection } \\
\text { (Positive samples/Replicates) }\end{array}$ \\
\hline 1 & $2 / 400$ & $1 / 4$ \\
2 & $0 / 400$ & $0 / 4$ \\
3 & $0 / 400$ & $0 / 4$ \\
4 & $2 / 400$ & $1 / 4$ \\
5 & $0 / 400$ & $0 / 4$ \\
6 & $0 / 400$ & $0 / 4$ \\
7 & $1 / 400$ & $1 / 4$ \\
8 & $0 / 400$ & $0 / 4$ \\
9 & $2 / 400$ & $2 / 4$ \\
10 & $0 / 400$ & $0 / 4$ \\
11 & $0 / 400$ & $0 / 4$ \\
12 & $0 / 400$ & $0 / 4$ \\
\hline
\end{tabular}

Journal of Seed Science, v.37, n.1, p.055-062, 2015 
Specifically for the detection of S. sclerotiorum in soybean seeds naturally infected or inoculated, Hennenberg et al. (2012), concluded that traditional tests described for the detection of that pathogen in soybean seeds, as paper roll, agar bromophenol blue medium and the blotter test aren't sensitive for the detection of the pathogen in seeds from areas with incidence the disease, but are efficient for detecting seed artificially inoculated. This study showed that the agar bromophenol blue medium and cPCR were efficient in detecting seeds infected by S. sclerotiorum in the same lots. For detection by cPCR an additional step as incubation time could be useful.

This extra incubation period before PCR may represent a viable alternative to increase the biomass of the fungus in the seed, diluting the influence of potential inhibitors during the incubation period and ensuring detection and quantification of viable organisms (Blanco-Meneses and Ristaino, 2013; Barrocas et al., 2009).

As mentioned PCR technique isn't be able to give information about incidence of pathogen in each sample. But since in this experiment the preincubation time used was the semi-seletive agar bromophenol blue medium, then there was extra information about incidence/lot and we could compare both techniques.

While the cPCR detected $S$. sclerotiorum at incidence level of $1 \%$ in seeds wich were incubated for 72 hours of the exposition time of the pathogen's colony, the same technique could detect $0,25 \%$ of the pathogen in seeds naturally infected using a preincubation time. This process has been adopted successfully by some authors for other pathosystems with success (Mbofung and Pryor, 2010; Ioos et al., 2012) and should be better investigated to reduce this period to be used in routine tests.

The use of the combined methods can improve the sensitivity of the pathogen detection. The molecular tests are the new alternative to solve it when intends detect small quantities of pathogen, but the choice of the most appropriated methodology to detect seed borne pathogen to represent the healthy conditions of a seed lot is still a challenge and must be investigated for each pathosystem.

\section{Conclusions}

The primers described by Freeman et al. (2002) are specific and suitable to detect $S$. sclerotiorum in soybean seeds inoculated and naturally infected.

The cPCR is suitable to detect $S$. sclerotiorum in soybean seeds inoculated with at least $1 \%$ of incidence and 72 hours of inoculum potential and in seeds naturally infected can detect
$0.25 \%$ when combined with incubation period.

The qPCR is suitable to detect $S$. sclerotiorum in soybean seeds inoculated with at least $1 \%$ of incidence and 24 hours of inoculum potential.

\section{Acknowledgements}

Thanks are due to the National Council for the Improvement of Higher Education (CAPES), to State Research Foundation of Minas Gerais (Fapemig) and to National Council for Scientific Research (CNPq) for their support to this research work.

\section{References}

BARROCAS, E.N.; MACHADO, J. C.; ALVES, M C.; CORRÊA, C.L. Desempenho de sementes de algodão submetidas à deficiência hídrica e presença de Colletotrichum gossypii var cephalosporioides. Bioscience Journal, v.30, n.2, p. 421-428, 2014. http://www.seer.ufu.br/index.php/ biosciencejournal/article/viewFile/17993/13757

BARROCAS, E.N.; MACHADO, J.C.; FIGUEIRA, A.R.; SOUZA, R.M.; ISHIDA, A.K.N.; ZACARONI, A.B.; ROCHA, H.S. Uso de técnicas moleculares para a diagnose de patógenos em sementes (Use of molecular techniques to pathogens seeds diagnose). Informe Agropecuário, v.30, n.253, p.24-32, 2009.

BECKER, J.; HACKL, M.; RUPP, O.; JAKOBI T.; SCHNEIDER, J.; SZCZEPANOWSK, R.; BEKEL, T.; BORTH, N.; GOESMANN, A.; GRILLARI, J.; KALTSCHMIDT, C.; NOLL, T.; PÜHLER, A.; TAUCH, A.; BRINKROLF, K. Unraveling the Chinese hamster ovary cell line transcriptome by next-generation sequencing. Journal Biotechnology, v.156, p.227-235, 2011. http://www.sciencedirect.com/science/article/pii/ S0168165611005517

BLANCO-MENESES, M.; RISTAINO, J.B. Detection and quantification of Peronospora tabacina using a Real-Time Polymerase. Plant Disease, v.95, n.6, p.673- 682, 2013. http://apsjournals.apsnet.org/doi/pdf/10.1094/PDIS$05-10-0333$

BOLAND, G. J.; HALL, R. Index of plant hosts to Sclerotinia sclerotiorum. Canadian Journal of Plant Pathology, v.16, n.2, p.93-108, 1994.

BRASIL. Ministério da Agricultura Pecuária e Abastecimento. Manual de Análise Sanitária de Sementes (Handbook on Seed Health Testing) Ministério da Agricultura, Pecuária e Abastecimento. Brasília: MAPA-ACS, 2009. 200p. http://www.agricultura.gov.br/arq_editor/file/12261_sementes_-web.pdf

BUSTIN, S.A. Why the need for qPCR publication guidelines? The case for MIQE. Methods, v.50, n.4, p.217-226, 2010.http://www-sciencedirect-com. ez26.periodicos.capes.gov.br/science/article/pii/S1046202309002618

CHEN, Y. Y.; CONNERA, R. L.; GILLARDC, C. L.; MCLAREND, D. L.; BOLANDE, D. L.; BALASUBRAMANIANF, P. M.; STASOLLAG, C.; ZHOUH, Q. X.; HWANGH, Q. X.; CHANGH, Q. X.; BABCOCKI, C. A quantitative real-time PCR assay for detection of Colletotrichum lindemuthianum in navy bean seeds. Plant Pathology, v.62, p.900-907, 2013. http://onlinelibrary.wiley.com/doi/10.1111/j.1365-3059.2012.02692.x/pdf 
COTTYN, B.; BAEYEN, S.; PAUWELYN, E.; VERBAENDERT, I.; VOS, P.; BLEYAERT,P.; HOFTE, M.; MAES, M. Development of a real-time PCR assay for Pseudomonas cichorii, the causal agent of midrib rot in greenhousegrown lettuce, and its detection in irrigating water. Plant Pathology, v.60, p.453-61, 2011. http://onlinelibrary.wiley.com/doi/10.1111/j.13653059.2010.02388.x/pdf

DURESSA, D.; RAUSCHER, G.; KOIKE, S.T.; MOU, B.; HAYES, R.J.; MARUTHACHALAM, K.; SUBBARAO, K.V.; KLOSTERMAN, S.J. A real-time PCR assay for detection and quantification of Verticillium dahliae in spinach seed. Phytopathology, v.102, p.443-451, 2012. http://apsjournals. apsnet.org/doi/pdf/10.1094/PHYTO-10-11-0280

FENG, C.; MANSOURI, S.; BLUHM, B.H.; DU TOIT, L.J.; CORRELL, J.C. Multiplex real-time PCR assays for detection of four seedborne spinach pathogens. Journal of Applied Microbiology, v.117, p.472-484, 2014. http:// onlinelibrary.wiley.com/doi/10.1111/jam.12541/pdf

FREEMAN, J.; WARD, E.; CALDERON, C.; MCCARTNEY. A polimerase chain reaction (PCR) assay for the detection of inoculums of Sclerotinia sclerotiorum. European Journal of Plant Pathology, v.108, n.9, p.877-886, 2002. http://download.springer.com/static/ pdf/293/art\%253 A $10.1023 \% 252 \mathrm{FA} \% 253$ A 1021216720024 . pdf?auth66=1412838790_f078f0ae28911d99dbf8e1d6528645ba\&ext=.pdf

GLYNN, N.C.; EDWARDS, S.G. Evaluation of PCR assay for quantifying seed-borne infection by Fusarium and Microdochium seedling blight pathogens. Applied Microbiology, v.108, p.81-87, 2010. http://onlinelibrary. wiley.com/doi/10.1111/j.1365-2672.2009.04410.x/full

HENNENBERG, L.; GRABICOSKI, E.M.G.; JACCOUD-FILHO, D.S.; PANOBIANCO, M. Incidência de Sclerotinia sclerotiorum em sementes de soja e sensibilidade dos testes de detecção. Pesquisa Agropecuária Brasileira, v.47, n.6, p.763-768, 2012. http://www.scielo.br/pdf/pab/v47n6/47n06a05.pdf

IOOS, R.; FOURRIER, C.; WILSON, V.; WEBB, K.; SCHEREFFER, J.L. DE LABROUHE, D.T. An optimized duplex realtime PCR tool for sensitive detection of the quarantine Oomycete Plasmopara halstedii in sunflower seeds. Phytopathology, v.102, p.908-917, 2012. http://apsjournals.apsnet. org/doi/pdfplus/10.1094/PHYTO-04-12-0068-R

KIM, T, G.; KNUDSEN, G.R. Quantitative real-time PCR effectively detects and quantifies colonization of sclerotia of Sclerotinia sclerotiorum by Trichoderma spp. Applied Soil Ecology, v.40, n.1, p.100-108, 2008. http:// www-sciencedirect-com.ez26.periodicos.capes.gov.br/science/article/pii/ S0929139308000565

KUAN, C.P., WU, M.T., HUANG, H.C., CHANG, H. Rapid detection of Colletotrichum lagenarium, causal agent of anthracnose of cucurbitaceous crops, by PCR and real-time PCR. Journal of Phytopathology, v.159, p.276-282, 2011. http://onlinelibrary.wiley.com/doi/10.1111/j.1439-0434.2010.01765.x/pdf
LING, K.S.; WECHTER, W.P.; WALCOTT, R.R.; KEINATH, A.P. Development of a real-time RT-PCR assay for squash mosaic virus useful for broad spectrum detection of various serotypes and its incorporation into a multiplex seed health assay. Journal of Phytopathology, v.159, p.649-656, 2011. http://onlinelibrary. wiley.com/doi/10.1111/j.1439-0434.2011.01814.x/pdf

MACHADO, J.C.; GUIMARAES, R.M.; VIEIRA, M.G.G.C.; SOUZA, R.M.; POZZA, E.A. Use of water restriction technique in seed pathology. Seed Testing International. ISTA News Bulletin, v.128, p. 14-18, 2004.

MACHADO, J.C.; POZZA, E.A. Razões e procedimentos para o estabelecimento de padrões de tolerância a patógenos em sementes (Reasons and procedures to establish tolerance standards of pathogens in seed). In: ZAMBOLIM, L. Sementes qualidade fitossanitária, Viçosa, MG: UFV, 2005. p.375-398.

MBOFUNG, G.C.; PRYOR, B.M. A PCR-Based assay for detection of Fusarium oxysporum f. sp. lactucae in lettuce seed. Plant Disease, v.94, n.7, p.860-866, 2010. http://apsjournals.apsnet.org/doi/pdf/10.1094/PDIS-94-7-0860

MICHEL, B. E.; RADCLIFFE, D. A computer program relating solute potential to solution composition for five solutes. Agronomy Journal, v.87, n.1, p.126-130, 1995.

MONTES-BORREGO, M.; MUNOZ-LEDESMA, F.J.; JIMENEZ-DIAZ, R.M.; LANDA, B.B. Real-time PCR quantification of Peronospora arborescens, the opium poppy downy mildew pathogen, in seed stocks and symptomless infected plants. Plant Disease, v.95, p.143-152, 2012. http:/ apsjournals.apsnet.org/doi/pdfplus/10.1094/PDIS-07-10-0499

ROGERS, S.L.; ATKINS, S.D.; WEST, J.S. Detection and quantification of airborne inoculums of Sclerotinia sclerotiorum using quantitative PCR. Plant Pathology, v.58, n.2, p.324-331, 2009. http://onlinelibrary.wiley.com/ doi/10.1111/j.1365-3059.2008.01945.x/pdf

SIQUEIRA, C. S.; MACHADO, J. C.; BARROCAS, E.N.; ALMEIDA, M.F. Potential for transmission of Stenocarpella macrospora from inoculated seeds to maize plants grown under controlled conditions. Journal of Seed Science, v.36, n.2, p.154-161, 2014. http://www.scielo.br/pdf/jss/v36n2/ v36n2a03.pdf

YANNI, Y.; DING, L.; LIU, X.; YANG, J.; MA, Z. Detection of Sclerotinia sclerotiorum in planta by a real-time PCR assay. Journal Phytopatology, v.157, n.7-8, p.465-469, 2009. http://onlinelibrary.wiley.com/doi/10.1111/ j.1439-0434.2009.01543.x/full 